\title{
In-vitro Evaluation of Chemotoxicants Inhibiting the Bacterial Leaf Spot Pathogen of Betelvine (Pseudomonas betle)
}

\author{
S. Hembram ${ }^{1 *}$, S. Baskey ${ }^{2}$ and D.C. Khatua ${ }^{3}$ \\ ${ }^{1}$ Regional Research Station, Terai Zone, ${ }^{2}$ Regional Research Station, Hill Zone, Uttar Banga \\ Krishi Viswavidyalaya, Cooch Behar, West Bengal, India \\ ${ }^{3}$ Department of Plant Pathology, Bidhan Chandra Krishi Viswavidyalaya, Nadia, \\ West Bengal, India \\ *Corresponding author
}

\section{A B S T R A C T}

\begin{tabular}{|l|}
\hline K e y w o r d s \\
$\begin{array}{l}\text { Pseudomonas betle, } \\
\text { Betelvine, } \\
\text { Fungicide, Bacterial } \\
\text { disease }\end{array}$ \\
\hline Article Info \\
\hline $\begin{array}{l}\text { Accepted: } \\
\text { 17 July 2018 } \\
\text { Available Online: } \\
\text { 10 August } 2018\end{array}$ \\
\hline
\end{tabular}

The betel vine crop is attacked by a number of fungal and bacterial pathogens and they cause many types of diseases to the plant. Among the bacterial diseases, leaf spot is more common in newly planted crop and baroj. Incidence of bacterial leaf spot and stem rot incited by Xanthomonas axonopodis pv. betlicola and Pseudomonas betle are common in all the cultivated varieties. In the present investigations ten fungicides are tested such as three systemic fungicides (Carbendazim 50\% WP, Benomyl 50\% WP, Metalaxyl 35\% WB), two contact fungicides (Mancozeb 75\% WB and Thiram), four copper fungicides (Copper oxychloride 50\% WP, Copper hydroxide 77\% WP and Copper sulphate based fungicide, Bordeaux mixture) and one combined formulation (Carboxin 37.5\%+ thiram $37.5 \%$ ). Among the ten fungicides, Carbendazim 50\% WP, Benomyl 50\% WP, Metalaxyl $35 \%$ WB were not potent inhibitors, but Carboxin 37.5\%+ thiram 37.5\%, a combined formulation showed inhibition against Pseudomonas betle. Mancozeb and Thiram also did not inhibit the growth of the bacteria at higher concentration. Therefore, these fungicides can be used for the management fungal as well as bacterial pathogens simultaneously.

\section{Introduction}

Betel vine (Piperis betle L.) is also known as Pan, Bhujangalata, nagavelli, jambuli, bhakhya patra, saptasira. The common varieties cultivated in India are Bangla, Meetha, Saanchi, Banarasi, Kapoori, Deshabari, Khasi. The betel leaf is cultivated in most of South and Southeast Asia (India, Nepal, Bangladesh and Sri Lanka) In India, betel vine is grown as an important cash crop in southern parts, mainly in the states of Andhra Pradesh, Karnataka, Kerala, and Tamil Nadu. Betel is also cultivated in Assam, Bihar, Madhya Pradesh, Maharashtra, Orissa, Tripura, Uttar Pradesh and West Bengal. Betel leaves has good export potential and India exports betel leaves to the countries like Pakistan, Bangladesh, Indonesia, Malaysia, Burma and Thailand. Cultivation of betelvine 
is highly specialized and is carried out with intensive care in terms of land preparation, choice of varieties, propagation, aftercare, control of pests and diseases and harvesting and marketing. Estimated Area under Betel vine Cultivation in West Bengal is 3000 ha. Betelvine is cultivated under artificially erected structure known as 'Boroj'. The moist shaded condition prevailing in Boroj favours vine growth but is also congenial for growth of pathogenic fungi and bacteria causing some destructive diseases (Maiti and Sen, 1979; Maiti, 1994; Maiti and Shivashankara, 1998). The diseases of serious proportion include Foot rot syndrome caused by number of pathogens including Phytophthora, Pythium sp., Rhizoctonia solani and Sclerotium rolfsii. A number of leaf spot diseases caused by different fungal and bacterial pathogens(Colletotrichum capsici, Drechslera rostrata, Cladosporium pipericola, Cercospora piperis, Corynespora cassicola, Phoma piperis-betle, Xanthomonas campestris pv. betlicola (Xanthomonas axonopodis pv. betlicola, Pseudomonas betle) have been reported which cause damage to betelvine (Maiti and Sen, 1979; Chattopadhyay and Maiti, 1990; Bardhan et al., 2002; Bhattacharya et al., 2003). Patel et al., (1925) and Raghunath (1926) fond that the leaf spot disease caused by Pseudomonas betlis quite destructive. Incidence of bacterial leaf spot and stem rot incited by Xanthomonas axonopodis pv. betlicola is common in all the cultivated varieties (Bhattacharya and Khatua, 2004; Bhattacharya et al., 2005). Xanthomonas axonopodis pv. betlicola causes severe damage of betel vine (Piper betle L.) in West Bengal by producing different types of leaf spots (small to large, circular to irregular, angular), marginal leaf blight, stem lesion and wilting of vines(Khatua et al., 2013). Initially symptom of the disease, which is usually most common during the monsoons, is the development of minute, water soaked spots between the veins on the lower surfaces of the leaves. Afterwards the spots become noticeable on the upper surfaces as dark, rounded or angular areas, encircled by yellow zones. The centres of the spots are stippled brown, later turning black and rotting. In the early stages of infection the individual spots measure up to one fifth of an inch in diameter, afterwards they combine into large, irregular, dead areas. Occasionally the central dead tissues of old spots fall out, and on inadequately infected vines the diseased leaves turn yellow and fall. In recent years, bacterial leaf spot (Xanthomonas axonopodis pv. betlicola \& Pseudomonas betle) is causing considerable damage to betel vine (Bardhan et al., 2002; Bhattacharya et al., 2003).

This bacterial disease causes extensive damage of betel vine in West Bengal (Bhattacharya et al., 2012). Among the several diseases bacterial leaf spot disease caused by Pseudomonas betle is gradually becoming a dominating disease in the states. (Bardhan, 2002). This study was conducted to test the sensitivity of chemotoxicant against bacterial pathogen (Pseudomonas betle) of betelvine in order to utilize the findings for chemical control of the disease.

\section{Materials and Methods}

Sensitivity of Pseudomonas betle towards chemotoxicants was tested by Fish Spine method (following agar diffusion principle). Ten milliliter of 48 hours old bacterial culture grown in potato sucrose peptone broth was poured aseptically to $200 \mathrm{ml}$ melted PSPA (approx. temperature $42^{\circ} \mathrm{C}$ ). Then the test bacterium mixed with melted PSPA medium was equally distributed to sterilized petriplates. For each concentration of a chemical nine fish spine were used and also for the control. Fish spines were dipped in the watch glasses or sterilized petri-plates filled with chemical solutions at the desired concentration. 
Table.1 In vitro screening of chemicals against Xanthomonas axonopodis pv. betlicola and Pseudomonas betle following fish spine method

\begin{tabular}{|c|c|c|c|c|}
\hline \multirow{3}{*}{ Chemicals } & \multicolumn{4}{|c|}{ Pseudomonas betle } \\
\hline & 1000 ppm & 500 ppm & 200 ppm & 100 ppm \\
\hline & \multicolumn{4}{|c|}{ Diameter of inhibition zone in $\mathrm{cm}$} \\
\hline Metalaxyl 35\% WS & NI & NI & NI & NI \\
\hline Carboxin37.5\%+thiram $37.5 \%$ & 2.8 & 2.3 & 1.8 & 1.50 \\
\hline Copper oxychloride $50 \%$ WP & $\mathrm{NI}$ & $\mathrm{NI}$ & $\mathrm{NI}$ & NI \\
\hline Mancozeb 75\% WP & NI & NI & NI & NI \\
\hline Copper sulphate based fungicide & NI & NI & NI & NI \\
\hline Benomyl 50\%, WP & NI & NI & NI & NI \\
\hline Carbendazim 50\% WP & NI & NI & $\mathrm{NI}$ & NI \\
\hline Thiram & $\mathrm{NI}$ & $\mathrm{NI}$ & $\mathrm{NI}$ & NI \\
\hline Copper hydroxide 77\% WP & $\mathrm{NI}$ & $\mathrm{NI}$ & $\mathrm{NI}$ & NI \\
\hline \multirow[t]{2}{*}{ Bordeaux mixture } & normal & 0.5 strength & 0.25 strength & \\
\hline & 1.23 & 0.94 & 0.35 & \\
\hline
\end{tabular}

NI - Not inhibited, Bordeaux mixture- lime: copper sulphate: water: 10g: 10g: 1000ml

Fig.1 Extent of sensitivity of Ps. betle towards carboxin $37.5 \%+$ thiram $37.5 \%$

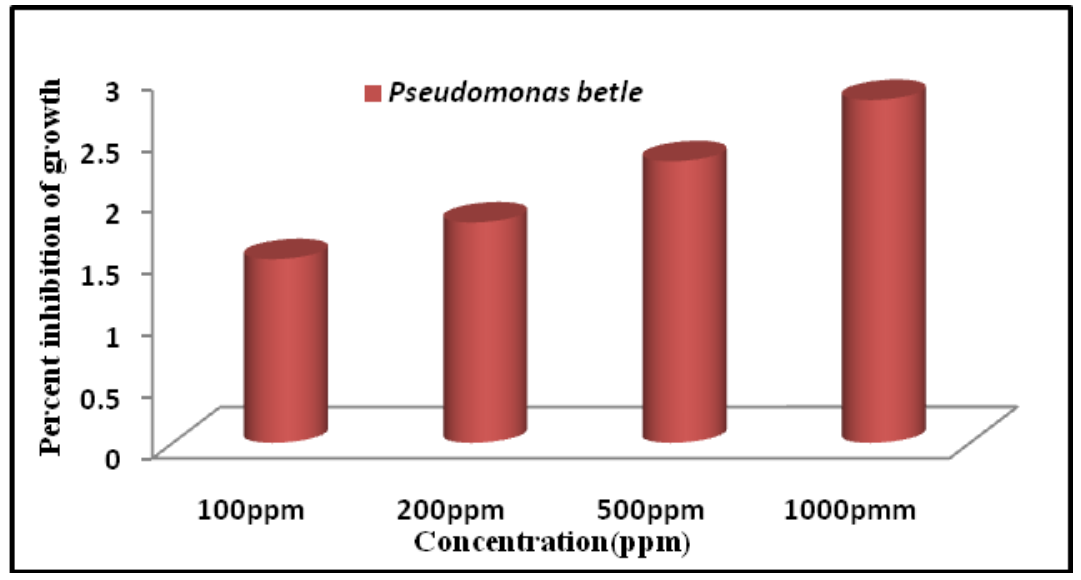

Fig.2 Extent of sensitivity of $P$ s. betle towards thiram

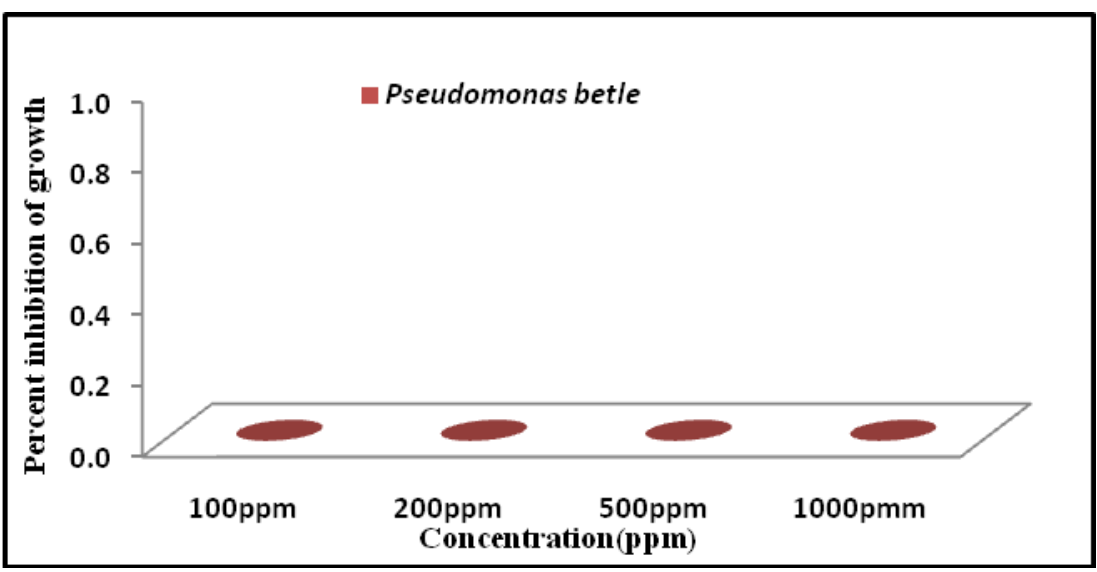


Fig.3 Extent of sensitivity of X. a.pv. betlicola and Ps. betle towards Bordeaux mixture

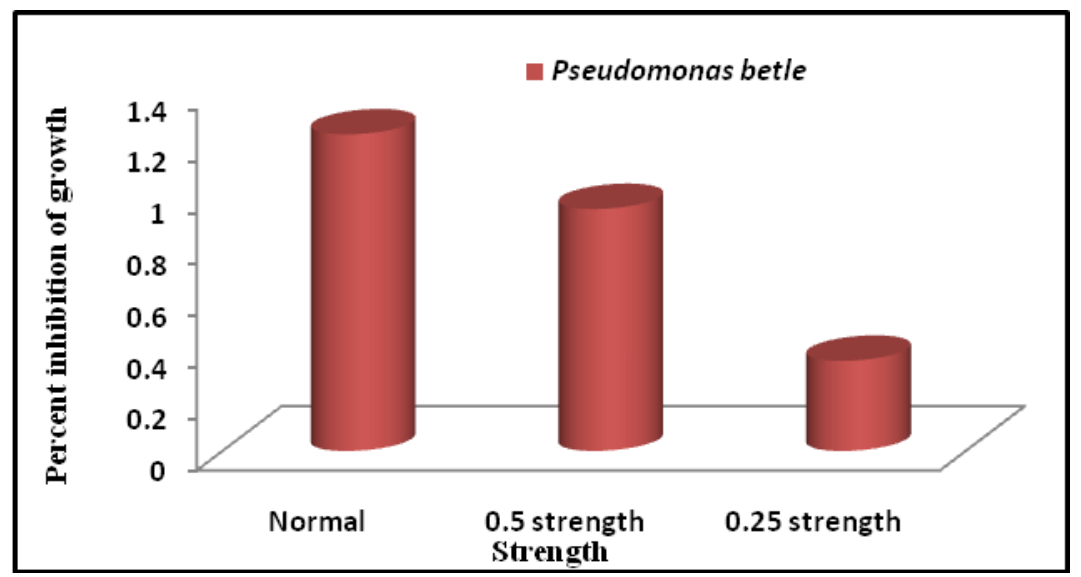

For each bacteria-seeded plate, 3 fish spines were taken with the help of sterilized forceps and put on agar medium. By the capillary action each fish spine picked up $0.05 \mathrm{ml}$ of chemical solution and the chemical spread radially over bacteria seeded PSPA medium. Then the plates were incubated at $28 \pm 1{ }^{\circ} \mathrm{C}$ for 48 hours after which observations were made to record the diameter of inhibition zones.

\section{Results and Discussion}

Bacterial leaf spot of betel (Piper betle), which caused considerable damage to the crop. In the present investigation 10 fungicides, against Pseudomonas betle (Table 1) by Fish spine method following agar diffusion principle at 100, 200, 500 and 1000 ppm were screened for their in vitro toxicity against the pathogen.

The fungicides showed variable response in inhibiting the colony growth of the pathogen according to their nature.

Among the ten fungicides, Copper oxychloride 50\% WP, Copper hydroxide 77\% WP and Copper sulphate based fungicide did not inhibited growth of Pseudomonas betle even at concentration of $1000 \mathrm{ppm}$. Bordeaux mixture showed some degree of inhibition
$(1.23,0.94$ and $0.35 \mathrm{~cm})$ against the bacteria (Figure 3).

Three systemic fungicides- Carbendazim 50\% WP, Benomyl 50\%, WP, Metalaxyl 35\% WB were not potent inhibitors even upto 1000ppm concentration, but Carboxin 37.5\%+ thiram $37.5 \%$ combined formulation showed inhibition against the bacteria (Figure 1). Mancozeb and Thiram inhibited growth of $X$. a. pv. betlicola at higher concentration (500ppm and 1000ppm) but did not inhibited growth of Pseudomonas betle even at concentration of 1000ppm (Fig. 2). In case of Xanthomonas axonopodis pv. betlicola similar result was observed by Khatua, et al.,(2013).

\section{References}

Bardhan, S., Bhattacharya R. and Khatua, D. C. (2002). Present status of bacterial disease of betelvine in West Bengal. Proceedings of National Seminar on Frontier studies in microbes and hostmicrobe interactions, organized by Indian Mycological Society, Kolkata, on February 2-3, 2002: 43 (abs).

Bhattacharya, R. and Khatua, D.C. (2004). Bacterial disease of betelvine in West Bengal: Nature of pathogens. Ind. Phytopathol., 57(3): 353(abs). 
Bhattacharya, R., Bardhan, S. and Khatua, D. C. (2003). Bacterial disease of betelvine - nature of pathogens. Accepted for presentation in National Symposium in Current Trends in Research on Microorganisms. Organized by Indian Mycological Society, Kolkata, on February 15-16, 2003: (abs).

Bhattacharya, R., Jana, M. and Khatua, D.C. (2005). Bacterial leaf spot and stem rot of betelvine in West Bengal. J. Mycol. Pl. Pathol., 35(3): 515 (abs).

Bhattacharya, R., Mondal, B., Ray S.K. and Khatua, D.C. (2012). A study on Bacterial disease of betelvine in West Bengal. Int. J. Bio-resou. Stress Manag., 3(2): 211-216.

Chattopadhyay, S. B. and Maiti, S. (1990). Diseases of betelvine and spices. ICAR, New Delhi pp. 1-32.

Khatua, D.C., Mondal, B. and Bhattachayya, R. (2013). A selective medium for
Xanthomonas axonopodis pv. betlicola, bacterial pathogen of betelvine. Afr. $J$. Agril. Res., 8(49): 6388-6393.

Maiti, S. (1994). Diseases of betelvine. In: Advances in horticulture. Vol.10. Plantation and spice crops. Part 2. (Eds. KL Chadha, P Rethinam). Malhotra Publishing House, New Delhi, India. pp. 1085-1097.

Maiti, S. and Sen, C. (1979). Fungal diseases of Betelvine. PANS, 25: 150-57.

Maiti, S. and Shivashankara, K.S. (1998). Betelvine research highlights (19811997). All India Coordinated Research Project on Betelvine, Indian Institute of Horticultural Research, Bangalore, India 21pages.

Patel, M. R., Kulkarni, R. S. and Dhande, G. W. (1951). Three bacterial diseases of plant. Curr. Sci. 20: 106.

Raghunathan, C. (1926). Bacterial leaf spot of betel leaf. Ceylon Dep. Agric. 39: 2.

\section{How to cite this article:}

Hembram, S., S. Baskey and Khatua, D.C. 2018. In-vitro Evaluation of Chemotoxicants Inhibiting the Bacterial Leaf Spot Pathogen of Betelvine (Pseudomonas betle). Int.J.Curr.Microbiol.App.Sci. 7(08): 2872-2876. doi: https://doi.org/10.20546/ijcmas.2018.708.303 